政体格体力棕合判定図（器）の使用成绕

平田研究所县 平田 欽 沼

昨年本学会:こおいてのぺた判定图（器）を実際に嗦用 1な実例仙ついて発表する。

\title{
一。 日本一煡康優良照童
}

昭和 28 年以降の日本一健康優良児童の湘定值を判定 してみると次の上らになり，各年度 男女共に +8 から

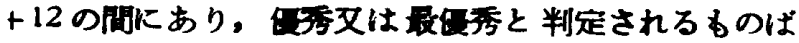
かりで，私の健康優良学徒侯械者の㟟拔基淮 +5 よりも 遥かに良好なものばかりである。

管 1 装

\begin{tabular}{|c|c|c|c|c|c|c|c|c|c|c|c|c|}
\hline $\mathbf{\nabla}$ & A & 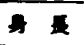 & 4 & 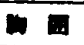 & 表 力 & n 力 & 力 & 4 & $\because$ & 4 力 & *合 & ;，定 \\
\hline 元 & 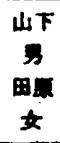 & $\begin{array}{r}14.6 \\
+9 \\
155.2 \\
+2\end{array}$ & $\begin{array}{r}500 \\
+2 \\
48.0 \\
+1\end{array}$ & $\begin{array}{r}80.5 \\
+2 \\
79.7 \\
+2\end{array}$ & $\begin{array}{r}7.9 \\
+1 \\
7.8 \\
+2\end{array}$ & $\begin{array}{r}2.20 \\
+2 \\
2.10 \\
+2\end{array}$ & $\begin{array}{r}55.0 \\
+2 \\
25.0 \\
+1\end{array}$ & & +7 & $\begin{array}{l}+5 \\
+5\end{array}$ & $\begin{array}{l}+12 \\
+10\end{array}$ & 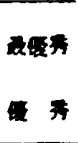 \\
\hline 童 & 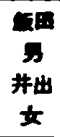 & $\begin{array}{r}158.8 \\
+4 \\
158.0 \\
+9\end{array}$ & $\begin{array}{r}50.5 \\
+1 \\
49.8 \\
+1\end{array}$ & $\begin{array}{r}9.0 \\
+1 \\
82.2 \\
+2\end{array}$ & $\begin{array}{r}8.0 \\
+1 \\
7.5 \\
+2\end{array}$ & $\begin{array}{r}2.04 \\
0 \\
2.40 \\
+2\end{array}$ & $\begin{array}{r}49 \\
+1 \\
36 \\
+2\end{array}$ & & +6 & $\begin{array}{l}+2 \\
+6\end{array}$ & $\begin{array}{r}+8 \\
+12\end{array}$ & 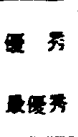 \\
\hline 言 & 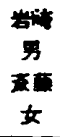 & $\begin{array}{r}162.0 \\
+4 \\
155.7 \\
+9\end{array}$ & $\begin{array}{r}53.1 \\
+1 \\
46.1 \\
+1\end{array}$ & $\begin{array}{r}81.7 \\
+1 \\
76.5 \\
+1\end{array}$ & $\begin{array}{r}7.2 \\
+2 \\
8.5 \\
+1\end{array}$ & $\begin{array}{r}2.13 \\
+1 \\
2.15 \\
+2\end{array}$ & $\begin{array}{r}54 \\
+2 \\
38 \\
+1\end{array}$ & & +6 & $\begin{array}{l}+5 \\
+4\end{array}$ & +9 & 缕 \\
\hline$\equiv$ & 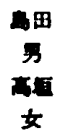 & $\begin{array}{r}156.9 \\
+9 \\
158.1 \\
+9\end{array}$ & $\begin{array}{r}49.0 \\
+1 \\
50.5 \\
+1\end{array}$ & $\begin{array}{r}80.6 \\
+1 \\
80.2 \\
+2\end{array}$ & $\begin{array}{r}7.9 \\
+1 \\
8.1 \\
+2\end{array}$ & $\begin{array}{r}2.25 \\
+? \\
1.87 \\
+1\end{array}$ & $\begin{array}{r}51 \\
+2 \\
56 \\
+2\end{array}$ & & +5 & +5 & $\begin{array}{l}+10 \\
+11\end{array}$ & 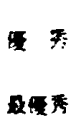 \\
\hline
\end{tabular}

二. 沾臭県美灌中学校の判定成表

この中学は美灌市の中心部にある約千名を容する学校 であるが、この学校の生徒は身長大疲型細胸の都市型体 格を示し，体力は走，跳，投共に良好で，粽合点では女 子は男子を凌駕し，二年は最良，一年が不良である。

綜合点の度数分布表を作成すると大部分㣖 +4 と -4 の間にあり，一名が+12, 一-11を示す特異なのるいた。 この中，私の基準による建康優良生徒候補者: 33 名， 発育不良 23 名，栄堆不良 90 名，体力不足 50 名，全体 的虚弱 31 名で，栄童不良（疲型細胸）が特汇多かつた。

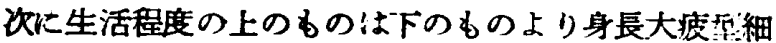
胸で，体力:士稍良好となつている。

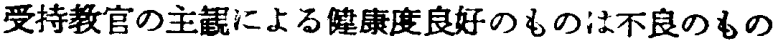

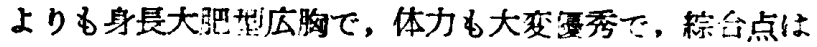
+2.32 と -2.50 とい5 著明な羑暴を示している。

B 式智能検 查,国語 +社会, 数学.理科, 保: 踺体青, 音楽の 成績の上のもの は下のむのミ・

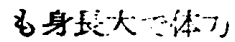
加優小，持二侧 健体育の成鿏々 の関䌽治著明 で, 粽合点て! 11.87 \& F $2.02 \div+\cdots$

\section{第 2 茫}

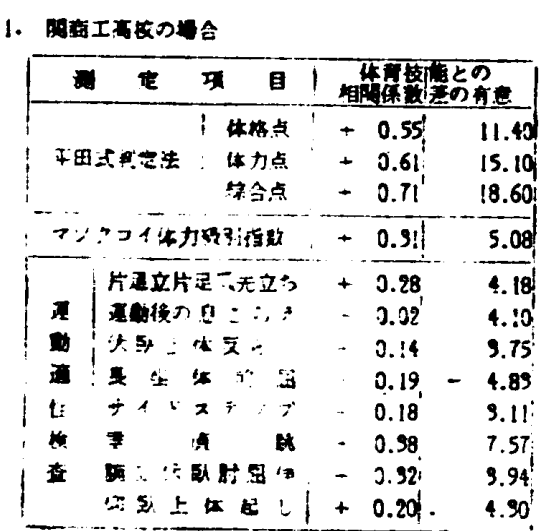

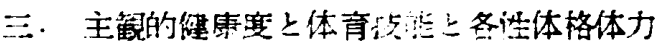
测定成箐との溇

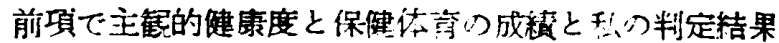
とには著明な関係を㗪めたのでず，現在体育界で一般

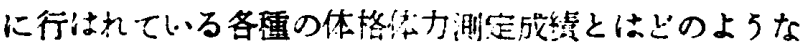
関係にあるかを此数研討するため，美港中三年男子 132 名と関商工高校 329 名の男于走对象と!て第二表の上5 な各種の测定を行つた。

1. 運動適性検查は各項目共に体青技能との相威が小

で、垂淔跳が僅かに+0.38を示すに過ぎない。

2. マックロ1氏体力級别指数は体育技能とは +0.4 ! 〜 0.31の㘕かな相関で, 体 重, 上膊囲の相関より小, 主観的健康度の上下の羑の 有意性も 7.45 で体重, 上罚 囲の $8.16,8.23$ より小さい。

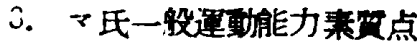
(GMCS)

各項目毎も，GMCS b共 にあまり体育技能，㑛康度 との相関度が高くない。

4. 肺活量, 背管力, 握力。 全般に大した相関はなく， 唯だ捚力が有意度が大き W.

5. 簢易心肺俰数は全、関保 がない.

6. 上膊国は割合に著明な相関があるが，体重と殆ん ど一致しているので、わさわさ測定誤差の多い上㙛 围は計らなくてもよい

7. 体格体力綜合判定法

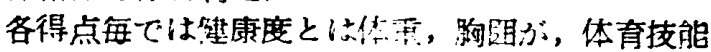
は体力特化投力か関係梁い，々して，綜合点は今回 の各種体格体力測定法中で，主兓的健康度，体育技 能との相関関保分㵊も深い、事を認め心。

然しながらこの成蛽各5名の受持教官による主観度 建康度判定と 2 名の体䓂教官に上る主観的体育技能評価 によるものであつて，この成綪さミナて，この体格体力綜

2. 类年中学媓の合

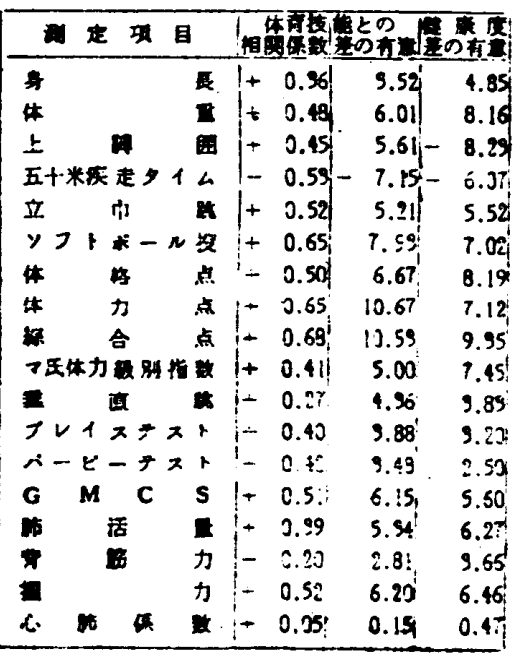

公判定法分㵊す 良いと断定する 事はできな!、

即枋, 少数の 受持教官や体育 教官の主観は必 ナ゙しも正確なる のではないの T, 多数の教官 の主勧による判 定の綜合が一番 望ましいので す.従つて,こ の結論を什寸讫 汇仿，全国各地 の多数の研究者 の追試が特に望 まれる次第で 